\title{
ANALISIS FAKTOR-FAKTOR YANG MEMENGARUHI PENERIMAAN PENGGUNA DALAM MENGGUNAKAN SISTEM ERP DENGAN STUDI KASUS PT XYZ
}

\author{
Yulianti dan Putu Wuri Handayani
}

Fakultas Ilmu Komputer, Universitas Indonesia, Kampus Baru UI Depok, Jawa Barat, 16424, Indonesia

\author{
E-mail: yulianti73@ui.ac.id
}

\begin{abstract}
Abstrak
Perkembangan ekonomi yang semakin cepat menyebabkan persaingan bisnis yang semakin ketat. Apalagi dengan adanya perkembangan teknologi yang semakin canggih, perusahaan-perusahaan tersebut berlomba-lomba dalam memanfaatkan teknologi untuk meningkatkan keunggulan kompetitif dan efisiensi kinerja perusahaan mereka dibandingkan pesaingnya. Salah satu investasi teknologi informasi yang populer saat ini adalah sistem Enterprise Resource Planning (ERP) yaitu paket aplikasi yang menawarkan "best practice" dalam menjalankan bisnis dengan menggunakan satu basis data yang dapat diakses oleh semua divisi dalam perusahaan. Terdapat banyak keuntungan yang dapat dirasakan oleh perusahaan dengan mengimplementasi sistem ERP, seperti mengurangi biaya produksi, meningkatkan integrasi data, dan mengurangi level inventori. Namun, sebagian besar implementasi sistem ERP yang telah dilakukan oleh beberapa perusahaan mengalami kegagalan. Salah satu faktor yang menyebabkan kegagalan ini adalah adanya resistensi pengguna terhadap perubahan. Resistensi dari pengguna ini juga menyebabkan perusahaan tidak dapat memaksimalkan keuntungan dari implementasi sistem ERP. Oleh karena itu, paper ini akan membahas mengenai faktor-faktor yang memengaruhi penerimaan pengguna dalam menggunakan sistem ERP. Faktor-faktor penerimaan ini didasarkan pada model penerimaan pengguna yang sudah ada pada penelitian sebelumnya yaitu model Unified Theory of Acceptance and Usage of Technology (UTAUT).
\end{abstract}

Kata Kunci: ERP, model penerimaan pengguna, UTAUT, resistensi pengguna

\begin{abstract}
An increasingly rapid economic development led to the increasingly stringent business competition. Especially with the development of increasingly sophisticated technology, these companies are competing in utilizing technology to enhance competitive advantage and efficiency of their company's performance than its competitors. One of the investment in information technology that is popular today is the Enterprise Resource Planning (ERP) system, is an application package that offers best practice of doing business by using a single database that is accessible by all divisions within the company. There are many advantages that can be felt by companies to implement ERP systems, such as reducing production costs, improve data integration, and reduce inventory levels. However, most implementations of ERP systems that have been done by some companies to fail. One of the factors that caused this failure is the presence of user resistance to change. Resistance from users has also led the company can not maximize the benefits of ERP system implementation. Therefore, this paper will discuss the factors affecting user acceptance of ERP systems in use. Acceptance factors are based on the user acceptance model that already exists in previous studies that model the Unified Theory of Acceptance and Usage of Technology (UTAUT).
\end{abstract}

Keywords: ERP, user acceptance model, user resistance, UTAUT

\section{Pendahuluan}

Perkembangan ekonomi yang semakin cepat di suatu negara menyebabkan persaingan bisnis yang semakin ketat. Kondisi tersebut mengharuskan perusahaan untuk meningkatkan kualitas dan keunggulan kompetitif dibandingkan pesaingnya agar perusahaan tersebut dapat bertahan dalam dunia bisnis. Seiring dengan perkembangan teknologi yang semakin cepat, perusahaan-perusahaan tersebut berlomba-lomba dalam memanfaatkan teknologi untuk meningkatkan efisiensi kinerja perusahaan mereka. Perusahaan rela mengeluarkan investasi teknologi informasi dalam jumlah besar untuk meningkatkan efisiensi dan efektivitas kinerja perusahaan [1].

Salah satu investasi teknologi informasi yang popular saat ini adalah sistem Enterprise Resource Planning (ERP). ERP merupakan sistem yang dapat membantu perusahaan dalam mengintegrasikan dan mengotomatisasi proses 
bisnis perusahaan, seperti finansial, penjualan, produksi, logistik, dan pengadaan. ERP adalah paket aplikasi yang menawarkan "best practice" dalam menjalankan bisnis dengan menggunakan satu database yang dipakai oleh semua divisi dalam perusahaan [2].

ERP dapat meningkatkan efektivitas dan efisiensi proses bisnis di perusahaan dengan meningkatkan keakuratan dan kecepatan dalam proses pertukaran data antara fungsi-fungsi bisnis. Sistem ERP merupakan solusi yang terintegrasi bagi perusahaan untuk mencapai sasaran bersaing yang kuat dengan kompetitor. Keuntungan yang bisa didapat perusahaan jika berhasil mengimplementasikan ERP, antara lain mengurangi biaya produksi, mempercepat kinerja proses bisnis, menigkatkan keakuratan data, meningkatkan integrasi antar fungsional area, mengurangi level inventori, dan lain-lain. Sistem ERP dapat membantu perusahaan untuk mengurangi biaya operasional perusahaan dan meningkatkan pengelolaan proses bisnis melalui integrasi antara fungsi-fungsi bisnis dan informasi [3][4].

Namun pada kenyataannya, sebagian besar implementasi ERP mengalami kegagalan. Menurut survei, sekitar $91 \%$ dari proyek implementasi sistem ERP selesai melebihi biaya yang direncanakan [4]. Berdasarkan peneltian Marinos tahun 2001, kegagalan implementasi sistem ERP dikarenakan kompleksitas implementasi, masalah integrasi, kekurangan dana, ketidaksesuaian penjadwalan proyek, dan resistensi pengguna terhadap perubahan [3]. Banyak pegawai perusahaan yang cenderung bereaksi negatif terhadap perubahan yang terjadi dengan adanya implementasi sistem ERP dan tidak terdorong untuk menggunakan sistem ERP. Resistensi pengguna ini menyebabkan perusahaan tidak dapat memaksimalkan keuntungan dari implementasi sistem ERP [5]. Pernyataan tersebut juga diperkuat oleh Indriani yang menyatakan bahwa salah satu hal yang menyebabkan perusahaan tidak mendapatkan manfaat dan keuntungan dari sistem ERP adalah adanya keengganan dan penolakan dari pengguna dan ketidakmampuan perusahaan untuk menentukan perubahan pada struktur organisasi sesuai dengan manfaat teknologi yang dipilih [4].

Oleh karena itu, paper ini akan membahas mengenai faktor-faktor apa saja yang memengaruhi penerimaan pengguna dalam menggunakan sistem ERP. Faktor-faktor penerimaan ini didasarkan pada model penerimaan pengguna yang sudah ada pada penelitian sebelumnya, yaitu model Unified
Theory of Acceptance and Usage of Technology (UTAUT) [5].

\section{Metodologi}

Model UTAUT merupakan model penerimaan pengguna yang dibuat dengan mengkombinasikan faktor-faktor dari delapan model penerimaan pengguna lainnya, yaitu Theory of Reasoned Action (TRA), Innovation Diffusion Theory (IDT), Task-Technology Fit (TTF), Motivation Model (MM), Theory of Planned Behavior (TPB), Model of PC Ulilization (MPCU), Combined TAM-TPB (C-TAM-TPB), dan Social Cognitive Theory (SCT) [5-7].

Model UTAUT yang digunakan dalam penelitian ini adalah model hasil modifikasi oleh Han Xue, Wang Xiaoyu, dan Wang Qian pada tahun 2009. Model UTAUT yang dikembangkan menghasilkan empat faktor utama dan empat faktor moderator yang dapat memengaruhi penerimaan pengguna yaitu faktor performance expectancy, effort expectancy, social influence, dan facilitating conditions. Empat moderator kunci pada model UTAUT adalah jenis kelamin, usia, pengalaman, dan pendidikan [5]. Pada makalah Han Xue, Wang Xiaoyu, dan Wang Qian yang berjudul "The Research on ERP Acceptance Model Based Unified Theory of Acceptance and Use of Technology", mereka menyimpulkan bahwa dukungan dari top management sangat memengaruhi penerimaan pengguna dalam menggunakan sistem ERP dan training sangat dibutuhkan untuk membiasakan pegawai dalam menggunakan sistem ERP.

Menurut penelitian Siskanovia tahun 2006, dengan menambahkan faktor technology trust, managerial intervention, dan habit pada model UTAUT, faktor-faktor yang memengaruhi penerimaan pengguna adalah faktor performance expectation, effort expectation, dan facilitating condition. Sedangkan faktor social influence, technology trust, managerial inventions, dan habit tidak memengaruhi penerimaan pengguna [8]. Kemudian, menurut Shuwei Huang dan Xueying, faktor-faktor pada model UTAUT yang memengaruhi penerimaan pengguna adalah performance expectation, effort expectation, social influences, dan facilitating condition. Shuwei Huang dan Xueying Wang juga menambahkan bahwa kesuksesan penggunaan ERP dapat ditingkatkan dengan cara memberikan training sesuai dengan tingkatan level karyawan dan perlunya pemberian penghargaan kepada karyawan yang berhasil menggunakan sistem ERP [5]. 


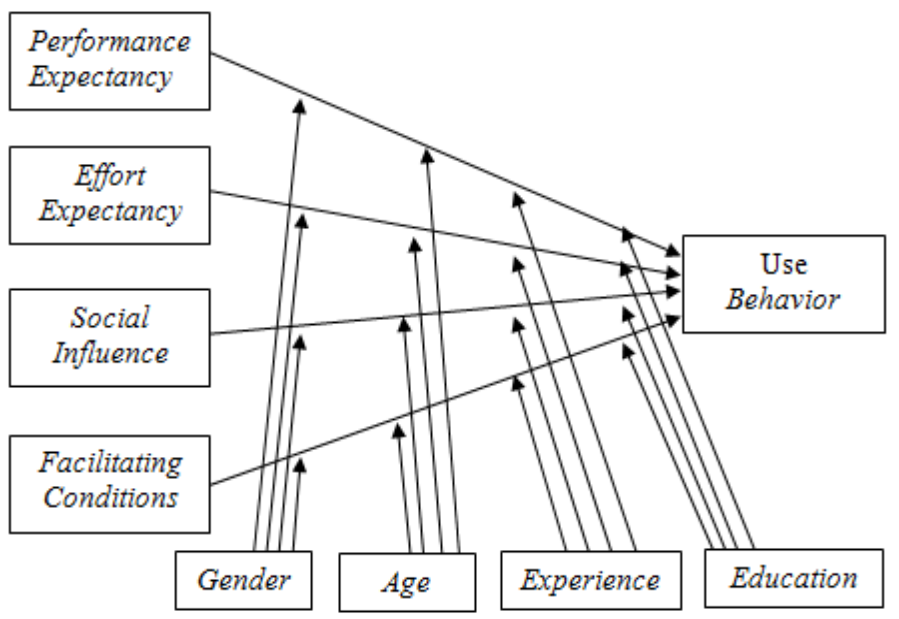

Gambar 1. Unified Theory of Acceptance and Usage of Technology (UTAUT).

Faktor-faktor yang ada pada model UTAUT tergambarkan pada gambar 1 [5], seperti performance expectancy, effort expectancy, social influence, facilitating conditions, serta faktor moderator. Performance expectancy merupakan tingkat di mana seorang individu percaya bahwa dengan menggunakan sistem akan membantu mereka untuk meningkatkan kinerja kerja. Faktor performance expectancy mengkonstruksi variabelvariabel dari beberapa model penerimaan pengguna terhadap teknologi, seperti perceived usefulness, extrinsic motivation, job fit, relative advantage, serta outcome expectation. Perceived usefulness didefinisikan sebagai tingkat persepsi seseorang terhadap suatu sistem informasi bahwa menggunakan sistem informasi tersebut akan meningkatkan performansi kerja mereka. Extrinsic motivation, didefinisikan sebagai persepsi bahwa pengguna mau melakukan suatu aktivitas dikarenakan pengguna merasa aktivitas tersebut merupakan alat untuk mendapatkan hasil yang bernilai seperti peningkatan kerja dan promosi. Job fit, didefinisikan sebagai keyakinan seseorang bahwa dengan menggunakan teknologi baru sesuai dengan pekerjaan mereka. Relative advantage, didefinisikan sebagai tingkat di mana inovasi dirasakan lebih baik dibandingkan pendahulunya. Outcome expectation, didefinisikan sebagai kemungkinan untuk mendapatkan hasil yang diharapkan setelah seseorang melakukan suatu tindakan.

Effort expectancy merupakan tingkat kemudahan dalam menggunakan sistem. Faktor effort expectancy mengkonstruksi variabelvariabel dari beberapa model penerimaan pengguna terhadap teknologi yaitu ease of use dan complexity. Ease of use, didefinisikan sebagai tingkat kemudahan atau kesukaran seseorang dalam menggunakan sistem baru (bebas dari usaha). Sedangkan complexity didefinisikan sebagai tingkat di mana inovasi dianggap sulit atau mudah untuk dimengerti.

Social influence merupakan kesadaran seseorang mengenai adanya orang lain yang menggunakan sistem. Faktor social influence membangun variabel-variabel dari beberapa model penerimaan pengguna terhadap teknologi yaitu subjective norm dan social factor. Subjective norm didefinisikan sebagai persepsi seseorang bahwa banyak orang penting yang berfikiran bahwa dia harus melakukan behavior yang diminta. Sedangkan social factor didefinisikan sebagai perasaan dalam diri seseorang terhadap kebudayaan suatu kelompok dan persetujuan interpersonal yang dibuat seseorang dengan individu lain dalam situasi sosial tertentu.

Facilitating conditions merupakan tingkat di mana orang percaya bahwa adanya fasilitas organisasi dan teknis yang mendukung mereka menggunakan sistem tersebut. Faktor facilitating conditions mengkonstruksi variabel-variabel dari beberapa model penerimaan pengguna terhadap teknologi seperti perceived behavioral control, facilitating condition, dan compatibility. Perceived behavioral control didefinisikan sebagai persepsi seseorang terhadap kemudahan atau kesukaran untuk membentuk suatu perilaku tertentu. Facilitating condition didefinisikan sebagai faktor-faktor lingkungan yang diobservasi dan disetujui sebagai hal yang memudahkan sesuatu untuk dilakukan, misalnya training, dukungan teknis, dan lain sebagainya. Compatibility, didefinisikan sebagai tingkat di mana inovasi dianggap konsisten dengan nilai yang ada dari pengalaman terdahulu. Faktor moderator terdiri dari faktor jenis kelamin, usia, pengalaman, serta pendidikan. 
Faktor jenis kelamin digunakan untuk mengetahui mayoritas jenis kelamin yang menggunakan sistem ERP. Faktor usia digunakan untuk mengetahui range usia yang menggunakan sistem ERP. Sedangkan faktor pengalaman untuk mengetahui sudah berapa lama pengguna menggunakan sistem ERP. Faktor pendidikan untuk mengetahui riwayat pendidikan dari pengguna sistem ERP.

\section{Hasil dan Pembahasan}

Untuk mengetahui apa saja faktor yang memengaruhi penerimaan pengguna terhadap sistem ERP, maka penulis melakukan studi kasus ke salah satu perusahaan yang bergerak di bidang telekomunikasi, yang sudah mengimplementasikan dan mengoperasikan sistem ERP lebih dari satu tahun. Studi kasus ini dilakukan melalui wawancara yang berisi pertanyaan-pertanyaan berdasarkan faktor-faktor pada model UTAUT dan penyebaran kuesioner yang berisi pernyataan-pernyataan berdasarkan faktor-faktor pada model UTAUT [9]. Responden yang diwawancara dan diminta untuk mengisi kuesioner adalah para pegawai yang menggunakan sistem ERP pada objek studi kasus.

Responden dari studi kasus ini adalah para pegawai dari departemen yang menggunakan sistem ERP, yaitu Departemen Procurement, Departemen Financial, Departemen Logistic, Departemen Network Planning, dan Departemen Enterprise Support System. Ada lima responden yang diwawancarai dan 23 responden yang mengisi kuesioner mengenai faktor-faktor penerimaan pengguna terhadap sistem ERP [10].

Penentuan responden ditentukan dengan berpegangan pada prinsip simple random sampling. Simple random sampling merupakan teknik pengambilan sampel secara acak tanpa memperhatikan strata [11]. Teknik simple random sampling diambil salah satunya karena penulis mengetahui jumlah populasi pengguna ERP pada perusahaan tersebut, serta pertimbangan waktu yang sempit dan tenaga yang sedikit.

Secara umum, hasil analisis dapat dilihat pada tabel I. Hasil analisis direkap berdasarkan prioritasi dari besarnya pengaruh faktor-faktor UTAUT terhadap penerimaan pengguna. Pada tabel I terdapat tiga kolom yaitu kolom pertama berisi faktor-faktor dari model UTAUT, kolom kedua merupakan ranking prioritas dari faktorfaktor UTAUT dan kolom ketiga merupakan alasan dari nilai prioritas yang diberikan kepada faktor-faktor UTAUT. Penilaian terhadap masingmasing variabel pada faktor-faktor UTAUT dihitung dengan menambah nilai masing-masing variabel yang dibagi dengan jumlah variabel untuk masing-masing faktor UTAUT. Hasil perhitungan 1 dianggap bernilai sangat besar, 2 sama dengan besar, 3 sama dengan agak besar, 4 sama dengan agak tidak besar, 5 sama dengan tidak besar, dan 6 sama dengan sangat tidak besar.

Faktor Performance Expectancy. Ada empat variabel pada faktor performance expectancy yang berpengaruh besar, yaitu perceived udefulness, job fit, relative advantage dan outcome expectation. Perceived usefulness berpengaruh besar disebabkan karena sebagian besar pengguna SAP merasakan adanya manfaat SAP bagi pekerjaan mereka, membuat pekerjaan mereka menarik, dan meningkatkan produktivitas mereka. Hal ini dikarenakan dengan menggunakan SAP, mereka dapat bekerja lebih cepat. Untuk faktor job fit, hal ini disebabkan karena sebagian besar pengguna SAP merasakan adanya kecocokan antara sistem SAP dengan proses bisnis dan cara bekerja mereka. Hal ini dikarenakan mereka dapat melakukan semua pekerjaan mereka menggunakan sistem SAP dan proses bisnis yang disediakan SAP memang sesuai dengan proses bisnis dari pekerjaan mereka walaupun masih dilakukan kostumisasi terhadap beberapa fitur SAP. Relative advantage berpengaruh besar disebabkan karena sebagian besar pengguna SAP merasakan implementasi SAP merupakan ide yang bagus dan lebih baik daripada sistem sebelumnya. Hal ini dikarenakan PT XYZ merupakan perusahaan yang tersebar di seluruh Indonesia dan memiliki banyak aplikasi terpisah. Untuk itu, diperlukan sistem yang terintegrasi yaitu sistem SAP. Outcome expectation disebabkan karena sebagian besar pengguna SAP merasakan hasil yang dikeluarkan SAP sesuai dengan harapan mereka, seperti informasi real time, kemudahan dalam menganalisis, pembuatan keputusan yang lebih cepat, dan keakuratan dalam pembuatan laporan.

Sedangkan variabel yang berpengaruh agak besar pada faktor performance expectancy, yaitu extrinsic motivation. Hal ini disebabkan karena hanya sebagian dari pengguna SAP merasakan adanya kesempatan untuk naik jabatan, mendapatkan intensif tambahan, dan adanya peningkatan kemampuan mereka. Hal ini dikarenakan mereka mendapatkan pengetahuan baru dengan menggunakan sistem SAP. Terdapat beberapa pegawai yang naik jabatan menjadi manajer karena mereka mengerti proses bisnis dan bisa menggunakan SAP. Namun, beberapa pegawai masih belum merasakan pengaruh penggunaan SAP terhadap kenaikan jabatan karena dinilai dari kinerja pegawai itu sendiri.

Variabel pada faktor effort expectancy yang berpengaruh besar, yaitu complexity. Hal ini disebabkan karena sebagian besar pengguna SAP 
merasakan bahwa untuk bisa memahami SAP memerlukan pengalaman/keahlian tertentu. Misalnya, untuk admin SAP, mereka harus menguasai fungsionalitas SAP dan bahasa ABAP. Sedangkan untuk end-user, mereka harus menguasai proses bisnis di departemen mereka. Mereka juga memiliki dorongan dalam diri mereka dan kepercayaan diri untuk menggunakan SAP. Hal ini dikarenakan SAP merupakan sistem yang global sehingga mereka bisa memiliki peluang kerja yang lebih besar baik di dalam maupun di luar negeri. Sedangkan variabel pada faktor effort expectancy yang berpengaruh agak besar, yaitu ease of use. Hal ini disebabkan karena hanya sebagian dari pengguna SAP merasakan kemudahan dalam menggunakan SAP karena sistem SAP kurang user-friendly.

TABEL I

PRIORITAS BERDASARKAN PENGaRUH FAKTOR-FAKTOR UTAUT TERHADAP PENERIMAAN PENGGUNA

\begin{tabular}{|c|c|c|}
\hline $\begin{array}{c}\text { Faktor } \\
\text { UTAUT }\end{array}$ & Prioritas & Alasan \\
\hline $\begin{array}{l}\text { Perfor } \\
\text { mance } \\
\text { Expect } \\
\text { ancy }\end{array}$ & 1 & $\begin{array}{l}\text { Dari lima variabel pada faktor } \\
\text { performance expectancy terdapat } \\
\text { empat variabel yang berpengaruh } \\
\text { besar dan hanya satu variabel yang } \\
\text { berpengaruh agak besar sehingga } \\
\text { persentase pengaruh dari faktor ini } \\
\text { sebesar } 80 \% \text {. }\end{array}$ \\
\hline $\begin{array}{l}\text { Effort } \\
\text { Expect } \\
\text { ancy }\end{array}$ & 2 & $\begin{array}{l}\text { Dari dua variabel pada faktor effort } \\
\text { expectancy terdapat satu variabel } \\
\text { yang berpengaruh besar dan satu } \\
\text { variabel yang berpengaruh agak } \\
\text { besar sehingga persentase } \\
\text { pengaruh dari faktor ini sebesar } \\
50 \% \text {. }\end{array}$ \\
\hline $\begin{array}{l}\text { Social } \\
\text { Influen } \\
\text { ces }\end{array}$ & 2 & $\begin{array}{l}\text { Dari dua variabel pada faktor } \\
\text { social influences terdapat satu } \\
\text { variabel yang berpengaruh besar } \\
\text { dan satu variabel yang } \\
\text { berpengaruh agak besar sehingga } \\
\text { persentase pengaruh dari faktor ini } \\
\text { sebesar 50\%. }\end{array}$ \\
\hline $\begin{array}{l}\text { Demog } \\
\text { rafi }\end{array}$ & 2 & $\begin{array}{l}\text { Dari empat variabel pada faktor } \\
\text { demografi terdapat dua variabel } \\
\text { yang berpengaruh besar dan dua } \\
\text { variabel yang berpengaruh agak } \\
\text { besar sehingga persentase } \\
\text { pengaruh dari faktor ini sebesar } \\
50 \% \text {. }\end{array}$ \\
\hline $\begin{array}{l}\text { Facilit } \\
\text { ating } \\
\text { Condit } \\
\text { ion }\end{array}$ & 3 & $\begin{array}{l}\text { Dari tiga variabel pada faktor } \\
\text { facilitating condition terdapat satu } \\
\text { variabel yang berpengaruh besar } \\
\text { dan dua variabel yang berpengaruh } \\
\text { agak besar sehingga persentase } \\
\text { pengaruh dari faktor ini sebesar } \\
33,33 \% \text {. }\end{array}$ \\
\hline
\end{tabular}

Pada awal penggunaan SAP, mereka kesulitan dalam menghafal transaction code (tcode) dan langkah-langkah di SAP. Untuk bisa mengoperasikan SAP, mereka harus mencoba sendiri, mengikuti training, serta memerlukan bantuan dari rekan kerja dan buku manual.
Walaupun mereka hanya memerlukan waktu kurang dari 3 bulan untuk bisa mengoperasikan SAP. Namun, untuk menjadi mahir dalam menggunakan SAP, mereka membutuhkan waktu kurang lebih satu tahun.

Variabel pada faktor social influence yang berpengaruh besar, yaitu subjective norm. Hal ini disebabkan karena sebagian besar pengguna SAP merasakan adanya dukungan dari top manajement, atasan, dan rekan kerja untuk menggunakan sistem SAP. Hal ini dikarenakan penggunaan SAP bersifat top-down, yaitu adanya paksaan dari top management. Sedangkan, variabel pada faktor social influence yang berpengaruh agak besar, yaitu social factor. Hal ini disebabkan karena hanya sebagian dari pengguna yang merasakan adanya symbol status dan bergengsi dalam menggunakan SAP, serta adanya peraturan-peraturan yang memaksa penggunaan SAP. Hal ini dikarenakan SAP hanya dianggap sebagai alat yang digunakan untuk mengerjakan tugas mereka.

Variabel pada faktor facilitating condition yang berpengaruh besar, yaitu facilitating condition karena sebagian pengguna merasakan adanya fasilitas yang disediakan dari perusahaan menunjang pengguna dalam menggunakan SAP seperti buku manual, training, helpdesk, dan pembekalan pengetahuan. PT XYZ memberikan training kepada end-user selama dua minggu. PT XYZ juga memberikan buku manual untuk mengoperasikan langkah-langkah proses bisnis yang ada di SAP kepada departemen terkait sesuai modul yang mereka gunakan. PT XYZ juga menyiapkan tim khusus yang bertanggung jawab untuk menangani masalah pengguna dalam menggunakan sistem SAP.

Terdapat dua variabel pada faktor facilitating condition yang berpengaruh agak besar, yaitu perceived behavioral control dan compatibility. Variabel perceived behavioral control disebabkan karena sebagian pengguna merasakan peningkatan pemahaman setelah mengikuti training. Namun, pemahaman pengguna bergantung dari daya tanggap mereka. Terdapat pengguna yang bisa mengoperasikan SAP setelah mengikuti training dan membaca buku manual. Tapi, ada juga pengguna yang belum bisa mengoperasikan SAP setelah di-training dan membaca buku manual. Mereka perlu bertanya berulang-ulang ke tim helpdesk untuk bisa mengoperasikan SAP. Mereka juga merasa cukup puas dengan fasilitas dan respons dari tim helpdesk yang disediakan perusahaan untuk membantu mereka dalam menggunakan SAP. Respons dari tim helpdesk paling lama satu jam dan untuk penyelesaian masalah paling lama satu hari tergantung dari urgency dari masalah tersebut. Sedangkan untuk 
faktor compatibility, hal ini disebabkan karena sebagian pengguna mendapatkan informasi mengenai implementasi SAP dan progress implementasi SAP melalui rapat. Selain itu, spesifikasi komputer yang sudah ada juga menunjang pengguna untuk menggunakan SAP.

Faktor Jenis Kelamin. Dikarenakan jumlah pengguna laki-laki hampir sama dengan jumlah pengguna perempuan, sehingga jenis kelamin tidak memengaruhi penerimaan pengguna karena baik laki-laki maupun perempuan bisa beradaptasi dengan sistem SAP.

Faktor Umur. Disebabkan karena pengguna SAP di PT XYZ masih relatif muda, yaitu 21 tahun sampai 35 tahun, sehingga usia ini berpengaruh dalam penerimaan pengguna terhadap sistem SAP, karena dengan usia yang relatif muda, mereka lebih bisa menerima teknologi baru dan lebih mudah dalam mempelajari teknologi tersebut.

Faktor Pendidikan. Tingkat pendidikan tidak terlalu memengaruhi penerimaan pengguna terhadap sistem SAP di PT XYZ, karena baik yang memiliki pendidikan S1 maupun D3 bisa beradaptasi terhadap sistem SAP karena adanya fasilitas pelatihan yang diberikan oleh perusahaan.

Faktor Pengalaman. Sebagian besar pengguna SAP sudah memiliki pengalaman menggunakan SAP bertahun-tahun. Hanya tiga orang yang baru memiliki pengalaman satu tahun. Hal ini menunjukkan bahwa lamanya pengguna dalam menggunakan SAP memengaruhi penggunaan SAP di PT XYZ karena semakin lama pengguna berpengalaman dalam menggunakan sistem SAP maka semakin mudah bagi mereka dalam menerima dan menggunakan sistem SAP.

\section{Kesimpulan}

Berdasarkan penelitian yang telah dilakukan dapat diambil beberapa kesimpulan. Pertama, faktor performance expectation memberikan pengaruh dalam penerimaan pengguna terhadap sistem ERP karena pengguna merasakan manfaat dari sistem ERP, kecocokan sistem ERP dengan pekerjaan mereka, kelebihan sistem ERP dibandingkan sistem sebelumnya, kemampuan ERP dalam memberikan hasil sesuai dengan harapan pengguna, serta peningkatkan kemampuan dan jabatan. Kedua, faktor effort expectancy yaitu kemudahan pengguna dalam menggunakan sistem ERP dan kompleksitas sistem ERP, memberikan pengaruh terhadap penerimaan pengguna.

Ketiga, faktor social influence memberikan pengaruh dalam penerimaan pengguna karena pengguna memerlukan pengaruh dari orang lain dan budaya perusahaan untuk menggunakan sistem ERP, seperti dukungan dari top management, dan adanya peraturan-peraturan. Keempat, faktor facilitating condition memberikan pengaruh terhadap penerimaan pengguna karena pengguna memerlukan fasilitas yang dapat mendukung. Kelima, faktor umur yang relatif muda memberikan pengaruh dalam penerimaan pengguna terhadap sistem ERP dikarenakan pengguna dengan umur relatif muda lebih mudah dalam menerima dan mempelajari sistem baru.

Keenam, faktor lamanya penggunaan ERP oleh pengguna memberikan pengaruh dalam penerimaan pengguna terhadap sistem ERP. Semakin berpengalaman seseorang dalam menggunakan sistem ERP, maka semakin mudah bagi mereka dalam menerima dan menggunakan sistem ERP. Selanjutnya, faktor jenis kelamin dan riwayat pendidikan tidak memengaruhi penerimaan pengguna karena baik laki-laki maupun perempuan dengan latar belakang pendidikan apa pun dapat menggunakan sistem ERP.

Terakhir, penelitian yang dilakukan oleh penulis memiliki beberapa keterbatasan, antara lain dalam hal jumlah responden dan level responden berdasarkan struktur organisasi. Hal ini disebabkan beberapa kelemahan pada instrumen, seperti pertanyaan yang diajukan untuk masingmasing pengguna cukup banyak dan panjang, beberapa pertanyaan yang diajukan kurang jelas dan deskriptif, pertanyaan yang diajukan untuk tiga jenis pengguna tidak dibedakan halamannya sehingga memungkinkan beberapa pengguna melakukan kesalahan dalam pengisian survei.

\section{Referensi}

[1] D. Amenike, "Analisis Dampak Intangible Dari Implementasi SAP di Perusahaan Multinational Studi Kasus PT XYZ," B.S Thesis, Faculty of Computer Science, Universitas Indonesia, Indonesia, 2010.

[2] E.F. Monk \& Wagner, Concept In Enterprise Resources Resource Planning, 3rd ed., Thomson, Boston, 2008.

[3] T. Marinos, "ERP Problem and Application Integration Issues: An Empirical Survey" In Proceedings of the 34th Hawaii International Conference on System Sciences, p. 9045, 2001.

[4] N. Indiani, "Model Penerimaan User dalam Implementasi Sistem ERP dengan Memodifikasi Model Technology Acceptance Model serta Memasukkan Karakteristik Individu User dan Organisasi," Ph.D Thesis, Industrial Engineering and 
Management, Institut Teknologi Bandung, Indonesia, 2006.

[5] S. Huang \& X. Wang. "Influence of Organization System to End-Users' Acceptance of ERP System in Chinese Enterprise" In HIS 2009 Ninth International Conference on, pp. 160-164, 2009.

[6] C.A. Gumussoy, F. Calisir, \& A. Bayram, "Understanding the behavioral intention to use ERP system: An extended technology acceptance model," Industrial Engineering and Engineering Management, 2007 IEEE International Conference on, pp. 20242028, 2007.

[7] S. AIAwadhi \& A. Morris, "The Use of the UTAUT Model in the Adoption of Egovernment Services in Kuwait," Hawaii International Conference on System Sciences, Proceedings of the 41st Annual, pp. 219, 2008.
[8] S. Noviaristant, "Model Penerimaan Sistem ERP (System Acceptance) Pada Fase Post Project," Ph.D Thesis, Industrial Engineering and Management, Institut Teknologi Bandung, Indonesia, 2006.

[9] W.C. John, Research Design Qualitative \& Quantitative Approaches, KIK Press, Jakarta, 2003.

[10] R. Krejcie \& D. Morgan, "Determining Sample Size For research Activities," Educational and Psychological Measurement, vol. 30, pp. 607-610, 1970.

[11] D.E. Hinkle, W. Wiersma, \& S.G. Jurs, Applied Statistics For The Behavioral Sciences, Haughton Mifflin Company, New York, 2003. 